\title{
Miranda
}

Revue pluridisciplinaire du monde anglophone /

Multidisciplinary peer-reviewed journal on the English-

speaking world

15 | 2017

Lolita at 60 / Staging American Bodies

\section{Poetry, Politics and Popcorn : Angels in America at the National Theatre}

Performance Review

\section{Alice Clapie}

\section{(2) OpenEdition}

\section{Journals}

\section{Electronic version}

URL: http://journals.openedition.org/miranda/11084

DOI: 10.4000/miranda. 11084

ISSN: 2108-6559

\section{Publisher}

Université Toulouse - Jean Jaurès

\section{Electronic reference}

Alice Clapie, "Poetry, Politics and Popcorn : Angels in America at the National Theatre", Miranda [Online], 15 | 2017, Online since 06 November 2017, connection on 16 February 2021. URL: http:// journals.openedition.org/miranda/11084 ; DOI: https://doi.org/10.4000/miranda.11084

This text was automatically generated on 16 February 2021

\section{(c) (†) $\ominus$}

Miranda is licensed under a Creative Commons Attribution-NonCommercial-NoDerivatives 4.0 International License. 


\section{Poetry, Politics and Popcorn : Angels in America at the National Theatre}

Performance Review

Alice Clapie

[Figure 1]

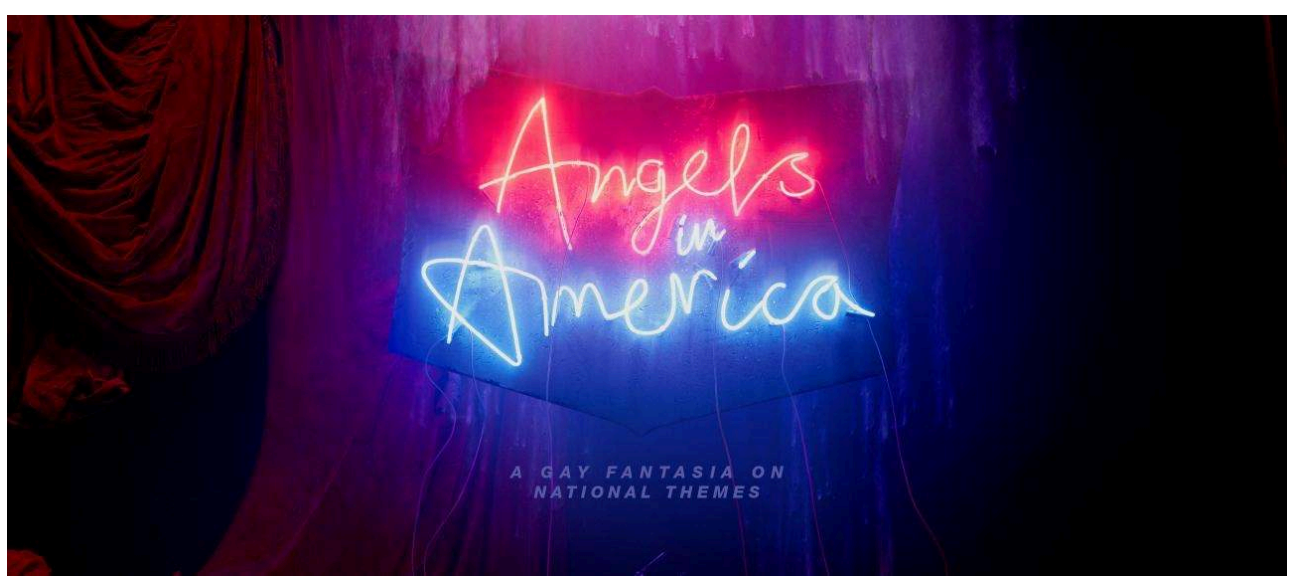

Credits : National Theatre, London

\section{Factual information about the shows}

1 Play: Angels in America: A Gay Fantasia on National Themes (1992), Millenium Approaches (3h30) and Perestroika (4h30).

2 Venue : Lyttelton Theatre (890), Royal National Theatre, London, UK.

3 Opening: Lyttleton Theatre, Thursday May 4, 2017.

4 Author : Tony Kushner.

5 Director : Marianne Elliott. 
Cast: Susan Brown (Hannah Pitt), Andrew Garfield (Prior Walter), Denise Gough (Harper Pitt), Nathan Lane (Roy M Cohn), Amanda Lawrence (The Angel), James McArdle (Louis Ironson), Nathan Stewart-Jarrett (Belize), Russell Tovey (Joseph Pitt), Stuart Angell, Laura Caldow; Claire Lambert, Becky Namgauds, Stan West, Lewis Wilkins (Angel Shadows).

Website : https://www.nationaltheatre.org.uk/shows/angels-in-america

Trailer : https://www.youtube.com/watch ?v =DinEV8NqKRo

\section{Review}

9 The National Theatre's $2017^{1}$ revival of Tony Kushner's multiple award-winning play Angels in America has all the characteristics of a box office hit. The production opened May 4, 2017 and ran until mid-August. Tickets soldout in the space of a few hours despite record high prices. Angels in America was commissioned in the late 1980s by the Eureka Theater Company, in San Francisco, at a time when the AIDS epidemic and the conservative turn of the 80s, prompted many artists to respond to the crisis. Kushner was one of them.

10 A very dense and complex text, Angels in America resists simple summarization. In "A Few Notes From the Playwright About Staging"Kushner insists that Millenium Approaches and Perestroika, partly because of their heterogeneous characters, are "two rather different plays, each with its own structure and character." ${ }^{2}$ Millenium Approaches is often compared to an explosion and Perestroika to its aftermath. ${ }^{3}$ Play-goers had the opportunity to see both plays in a day (with five intermissions) or to see them separately. But Kushner believes that "once engaged, audiences rediscover the rewards of patience and effort and the pleasures of an epic journey. An epic play should be a little fatiguing." ${ }^{\prime 4}$ While Kushner claims the political and aesthetic influence of Brecht and Marx in his work, Angels in America is a double-edged epic play. Depending on the director's choices, the performance of Angels can turn epic or just not $;^{5}$ the epic potential of the play actually depends on the performance. The National Theatre's revival of Angels in America brought together poetry, political drama, and entertainment: "Poetry, Politics and Popcorn." 6

11 The program drew the audience's attention to the contemporaneity of the play by highlighting connections between the 1980s and today. It displayed photos symbolizing the Reagan-Thatcher era and had articles dedicated to immigration ("Great Voyages"), to the evolution of AIDS since the 80s, or to Roy Cohn, Ed Koch (mayor of NYC in the 80s)and Donald Trump ("The Serpent and the Big Apple"). While underlining the political implications of the play, the production targeted a mass audience. And it reached its goal. A comic tone based on cultural stereotypes and pop-culture dominated the production against the backdrop of a highly poetic performance of suffering, love and political indictment. The production was fatiguing as expected. But it ended with an electrifying standing ovation and I think we experienced the effort, the patience, the pleasure and the reward of an epic journey.

Despite being roughly seven hours long, the production was entertaining and poignant enough for the audience to be liable to burst into laughter at any time. Dark humor, camp humor, and parody helped mingle entertainment and politics or controversial subjects as the production enhanced the topical themes of racial, sexual, gender, and 
national identity. Characters dying of AIDS, or depressed characters, are actually the ones that would make the audience laugh or smile the most. Stereotypes, crossdressing and references to popular culture too. Louis's monologue about race and racism, playing on stereotypes of Britishness received thunderous applause for example.

Louis : Well, no, but when the race thing gets taken care of-and I don't mean to minimalize how major it is, I mean I know it is, this is a really incredibly racist country but it's like,well, the British. I mean, all these blue-eyed pink people. [...]

Alongside the comic tone, the production could be qualified as a machine-play as the use of special effects or even spectacular choreographies on the Italian stage of the Lyttelton Theatre were at the same time highly entertaining and very poetic. In the text, when he first encounters the Angel of America, Prior cries out "Very Steven Spielberg." Prior's reference to Steven Spielberg is first and foremost a reference to theatrical illusion as Spielberg is famously known for his escapist movies in the 70s and 80s using developing technologies in film making. In fact, the National Theatre followed Kushner's idea that “it's OK if the wires show, and maybe it's good that they do, but the magic should at the same time be thoroughly thrilling, fantastical, amazing."

This staging alternated between machines and gestus, an acting technique developed by Brecht that emphasizes the social status of characters through body language, gaze, attitude and intonations. From the opening of the play to the middle of Millenium Approaches, the set was made of three turning blocks that enabled split scenes to "work out psychologically coherent (hence playable)". ${ }^{8}$ The three turning blocks would at the same time create separate spaces and unite the events occurring at the same time. But it also rendered the show more entertaining and dynamic as the audience would never be looking into the abyss of an empty stage. The change of set occurred with the lights on and the three turning blocks were replaced by an empty space that would be used mainly when fantastic elements were played out (ghosts, hallucination, dreams, angels etc.).

15 It is tempting to say that the staging alternated between realism and abstraction. Private spaces were enclosed spaces on stage and they required more props and detailed settings. Public spaces and imaginary places on the other hand, were mainly taking place on an empty stage with only one door standing for example, or the angel statue of the Bethesda fountain, or a purple-neon ladder leading to heaven, or a bench, symbolizing the type of space where the scene was taking place. The use of neon lights, rain, and snow added to the symbolist side of the staging that aimed at symbolizing public spaces while realizing private ones. However, the more the show was going on, the less the set was busy, and the more abstract the staging was.

The aesthetic choices enhanced alterity and alienation. The alternation between realistic, symbolistic and futuristic tableaux reflected the polymorphic universe of the play. This alternation resulted in the creation of reassuring and menacing atmospheres in between which characters and the audience were caught. The production seemed to associate mainstream West End/Broadway aesthetic with very-Steven-Spielberg futuristic elements. For example, the set for the "Council Room of the Hall of the Continental Principalities in Heaven,"at the end of Perestroika, could, oddly enough, remind the audience of the interior of a Tardis, the vessel of the extremely well-known (in Britain 
at least) Dr Who(s). Possibly even more striking were the post-urban motifs that highlighted the aftermath of an era.

The representation of the Angel of America was a unique combination of machinery and gestus. Carried by six "angel's shadows"this Angel of America can be related to a seraph, a type of angel, described in the Bible as celestial beings with six wings. ${ }^{9}$ The poetic choreographic performance of this character derived from both the phantasmagoric and the organic as her motion was hybrid, made of machine and actors. The dancers carrying the Angel would manually activate the beating wings and synthetic sound would raise or modify her voice. By representing the Angel of America as a weak, wounded, and aggressive angel (which is not often the case), the performance also presented the connection of characters with religion as one that is dwindling. The actress's performance was faithful to Kushner's openly acknowledged reverence for Brecht. In addition to the Angel's gestus and sets emphasizing alienation and alterity, the production used distanciation effect (Verfremdungseffekt). Acting was, to some extent, exaggerated so that identification could not be possible. It relied on stereotypes which were also a great part of the comic tone of the production.

The 2017 National Theatre production of Angels in America seems overall to popularize (in the sense that it made it more accessible) a play about the struggle of the gay community in the early days of the AIDS epidemic. Yet, if its popular success is in part due to the mainstream aesthetic of the play, or a cast gathering actors who have recently been seen in blockbuster movies and popular TV-shows, ${ }^{10}$ or even an emphasis on popular culture and the comic tonality, its popularity in 2017 bears witness to the work's universal message. The production met Kushner's expectations of a balance between entertainment and serious art, and the play, of which the reading is an immediate necessity, ${ }^{11}$ has reached a mass audience this year. The staging of this revival of Angels in America was very promising and it sure kept its promises even if the "mainstreamness" of a National Theatre production was surprising. Let's say that it has at least brought a mass audience to the theater to see a play about topical issues, and there was epic, there was magic, and there was poetry, politics and popcorn too.

\section{NOTES}

1. The National Theatre staged the play for the first time in the UK in 1992 and 1993.

2. Kushner, Tony. Angels in America: A Gay Fantasia on National Themes. [1992] Revised Edition with an Introduction by Tony Kushner. New York: Theater Company Press, 2013. 311.

3. ibid.311-312."Perhaps it can be said that Millenium is a play about security and certainty being blown apart, while Perestroika is about danger and possibility following the explosion. The events in Perestroika proceed from the wreckage made by the Angel's traumatic entry at the end of Millenium. A membrane has broken; there is disarray and debris. All of which is to suggest that, especially when the two parts of 
Angels are produced in repertory, the differences should be visible and palpable onstage."

4. ibid. 312 .

5. Reinelt, Janelle. "Notes on Angels in America as American Epic Theater" in Bloom, H.

(ed.). Tony Kushner.N.p.: Chelsea House Publisher, 2005.

6. "[As a graduate student at NYU, Tony Kushner] co-founded a theatre company called 3P Productions, using the three p's in politics, poetry and popcorn" Nielsen, Ken. Tony Kushner's Angels in America. Continuum, 2008, 10.

7. Kushner, op. cit. 313

8. Kushner, op. cit. 314

9. Carroll, Robert and Stephen Pricket (eds.). The Bible Authorized King James Version.

Oxford: Oxford University Press, 1997.

10. Andrew Garfield (The Social Network, The Amazing Spiderman), Nathan Stewart-Jarrett (Misfits), James McArdle (Star Wars)

11. Laville, Pierre. "Jacob en lutte avec l'ange de l'Amérique."Preface to Kushner, Tony. Angels in America. trans. Pierre Laville. 1992. Paris: L'avant scène théâtre, collection des quatre vents, 2007.9.

\section{ABSTRACTS}

Theater review of Angels in America by Tony Kushner directed by Marianne Elliott at the National Theatre of London, UK, May - August 2017.

Critique théâtrale d'Angels in America de Tony Kushner et mis-en-scène par Marianne Elliott au National Theatre (London, UK), mai - août 2017.

\section{INDEX}

Subjects: Theater

Mots-clés: Tony Kushner, Angels in America, théâtre épique, théâtre politique, divertissement vs. art, West End vs. théâtre non-commercial

Keywords: Tony Kushner, Angels in America, epic theater, political theater, entertainment v. art, West End v. "non-commercial"theater

\section{AUTHOR}

\section{ALICE CLAPIE}

M2 Etudes du Monde Anglophone, CAS, UT2J, Toulouse

alice.clapie@gmail.com 